\title{
The limnological characteristics and zooplankton community of a newly created site: The Pareja Limno-reservoir
}

\author{
Eugenio Molina-Navarro ${ }^{1, *}$, Silvia Martínez Pérez ${ }^{1}$, Antonio Sastre Merlín ${ }^{1}$ and Delia Martín \\ del $\mathrm{Pozo}^{2}$ \\ ${ }^{1}$ Department of Geology, Faculty of Sciences, University of Alcalá, Ctra. Madrid-Barcelona Km. 33.6, C.P. \\ 28871, Alcalá de Henares, Madrid, Spain. \\ 2 Centre for Hydrographic Studies (CEDEX), Paseo Bajo Virgen del Puerto 3, C.P. 28005, Madrid, Spain. \\ * Corresponding author: eugenio.molina@uah.es
}

Received: 25/10/2010

Accepted: 26/10/2011

\begin{abstract}
The limnological characteristics and zooplankton community of a newly created site: The Pareja Limno-reservoir

The creation of dams in the riverine zone of large reservoirs is an innovative action whose primary goal is to create water bodies that ensure a stable level of water there.. We have termed these bodies of water "limno-reservoirs" because their water level becomes constant and independent of the fluctuations occurring in the main reservoir. In addition, limno-reservoirs represent environmental initiatives with corrective and/or compensatory effects. Pareja Limno-reservoir, located near the left side of Entrepeñas Reservoir (Guadalajara province, central Spain), is one of the first initiatives of this type. We are investigating the hydrology, limnology, microbiology, siltation risk and other aspects of this site.

This paper focuses on the limnological study of the Pareja Limno-reservoir. To conduct this research, twelve seasonal sample collections at two sampling points (the dam and inflow zones) have been made in Pareja Limno-reservoir (spring 2008-winter 2011). The primary goal of this study is to describe the limnological characteristics of the limno-reservoir, with especial interest in the study of the zooplankton community.

The results of the study show that the Pareja Limno-reservoir follows a warm monomictic water stratification pattern. The highest nutrient concentrations were found in the winter, whereas the highest chlorophyll $a$ and phytoplankton biomass values (dominated by Bacillariophyta) were found in the summer and autumn. The results obtained suggest that the Pareja Limnoreservoir is oligo-mesotrophic. The total zooplankton species richness was high, especially in the inflow zone. The most frequently found species are in agreement with those described in other studies performed on the Iberian Peninsula. Rotifers and copepods showed higher relative abundances than cladocerans.
\end{abstract}

Key words: Limnological characteristics, limno-reservoir, zooplankton.

\section{RESUMEN}

Características limnológicas y comunidad zooplanctónica en un ecosistema de nueva creación: el Limnoembalse de Pareja

Los denominados diques de cola constituyen una actuación novedosa cuyo objetivo es generar una lámina de agua constante en sectores de cola de grandes embalses. Para dichas masas de agua hemos propuesto el término "limnoembalses", pues con ellos se genera permanencia en el nivel del agua frente a las variaciones inherentes a la gestión del embalse ordinario, suponiendo además una actuación ambiental de carácter compensatorio y/o corrector. El Limnoembalse de Pareja, ubicado en la margen izquierda del embalse de Entrepeñas (provincia de Guadalajara, España central), es una de las primeras actuaciones de este cariz. Por ello, nuestro equipo está realizando estudios relacionados con el comportamiento hidrológico, limnológico, microbiológico y su riesgo de aterramiento, entre otros aspectos.

Este artículo se centra en el estudio limnológico del Limnoembalse de Pareja. Para llevar a cabo dicha investigación, se han realizado en dos puntos de muestreo (presa y cola) doce muestreos estacionales (primavera 2008-invierno 2011). El principal objetivo del estudio es describir las características limnológicas del limnoembalse, poniendo además especial interés en el estudio de la comunidad zooplanctónica. 
Los resultados obtenidos muestran que el Limnoembalse de Pareja sigue una dinámica de lago monomíctico templado. Las concentraciones más elevadas de nutrientes se encontraron en invierno, sin embargo, los mayores valores de clorofila a y biomasa de fitoplancton (dominada por Bacillariophyta) fueron obtenidos en verano y otoño. Los resultados sugieren un estado oligo-mesotrófico de las aguas del limnoembalse. La riqueza total de especies de zooplancton fue elevada, especialmente en la zona de cola. Las especies más frecuentemente encontradas coinciden con aquellas descritas en otros lagos y embalses de la Península Ibérica. Los rotíferos y los copépodos mostraron abundancias relativas mayores que los cladóceros.

Palabras clave: Características limnológicas, limnoembalse, zooplancton.

\section{INTRODUCTION}

The water levels of large reservoirs in areas with a Mediterranean climate vary widely due to exploitation and climatic conditions. These variations produce undesirable effects on the environment, on the landscape (including the "arid band" phenomenon) and on the socio-economic development of their surroundings. The Entrepeñas Reservoir (south of Guadalajara province, central Spain), with a capacity of $835 \mathrm{hm}^{3}$ and $3213 \mathrm{hm}^{2}$ of potential inundation area, is one of these reservoirs. In addition, this reservoir shows higher vulnerability because of the transfer of significant volumes of water to southeastern Spain. The inhabitants of the region began to demand corrective and/or compensatory actions for these environmental effects in the 1990s. In 2006, their protests led to the construction of a small dam in a sidearm of the Entrepeñas Reservoir, in its riverine zone, next to the village of Pareja, which allows the development of a small body of water with a constant level. Dams of this type are known as "riverine dams" or "flood dams" (incorrectly translated from Spanish as "edge dams" by Molina-Navarro et al., 2010) and produce a body of water that is independent of the management of the main reservoir. We have termed these bodies of water "limno-reservoirs" because they resemble a lake more than a reservoir (Molina-Navarro et al., 2010).

The first initiatives of this type in Spain were proposed in the late 1980s and the early 1990s. Their primary aim was the creation of a suitable habitat for birds (Rodríguez Cabellos, 1995; Ministerio de Medio Ambiente y Comité Nacio- nal Español de Grandes Presas, 1996). Nevertheless, the Pareja Limno-reservoir is the first to have a dual function: environmental and recreational. It is open for swimming or for walking, and it has a jetty for motorless craft. These features promote the economic development of the area in terms of nature tourism. From an environmental perspective, it has two artificial islands that act as bird refuges. In addition, it has a fish ladder. No data describing this type of initiative worldwide have been found in the literature.

Because of the innovative nature of this water management initiative and coinciding with the end of the process of filling the reservoir, we have set up an environmental observatory at the Pareja Limno-reservoir. Our main aim is to study its feasibility from a multidisciplinary perspective. This project started in 2008 and is still being conducted. A number of studies are included in the project, including a monitoring program that addresses the physico-chemical, limnological, and microbiological aspects of the water body.

The limnological study is of particular interest in the light of the European Water Framework Directive (OJEU num. 327, 2000), whose objective is to achieve a "good ecological status" in every aquatic ecosystem by 2015 . Hence, at the beginning of 2008, a sampling protocol was designed to monitor a large number of limnological variables. These variables included the water body's physicochemical characteristics, nutrient content, transparency, chlorophyll $a$ content and taxonomic determinations of phytoplankton and zooplankton.

The purpose of this paper is to describe the physico-chemical and biological characteristics of the Pareja Limno-reservoir by studying the 
stratification patterns, the main limnological parameters, the trophic state and the phytoplankton population dynamics of the water body. However, particular emphasis is placed on the study of the zooplankton community, as recent zooplankton studies in Iberian lakes and reservoirs are scarce (e.g., Conde-Porcuna et al., 2004; Baião \& Boavida, 2005; Parra et al., 2009). The richness and the relative abundance of the different species in the three primary groups (copepods, rotifers and cladocerans) and the seasonality of these groups of zooplankton were investigated in this study.

\section{MATERIALS AND METHODS}

\section{Study site}

The Pareja Limno-reservoir is adjacent to the village of the same name, southern Guadalajara province (Spain) at the head of the Tajo River Basin (Fig. 1). It has a capacity of $0.94 \mathrm{hm}^{3}$ and a potential inundation area of $26 \mathrm{hm}^{2}$. Its maxi- mum depth is approximately $9 \mathrm{~m}$ near the dam. It becomes progressively shallower towards the inflow section, where it measures $1.5 \mathrm{~m}$. It is fed by the Ompólveda River, which has an $87.8 \mathrm{~km}^{2}$ basin. The main tributary of the river is the Valdetrigo stream, which flows from the northeast.

\section{Sampling strategies}

The sampling and laboratory analyses were performed in collaboration with a specialised team of the Centro de Estudios Hidrográficos (Spanish Ministry of the Environment). Twelve sample collections were made seasonally. These collections began at the beginning of the study in spring 2008 and ended in winter 2011. Two sampling points were selected. One of these points was located next to the dam of the limno-reservoir, and another was located in the inflow section. All of the samples were collected between 10:00-11:30 am.

Samples of $250 \mathrm{ml}$ were collected in plastic bottles from the surface of the water body to analyse nitrogen compounds, whereas $100 \mathrm{ml}$ ster-

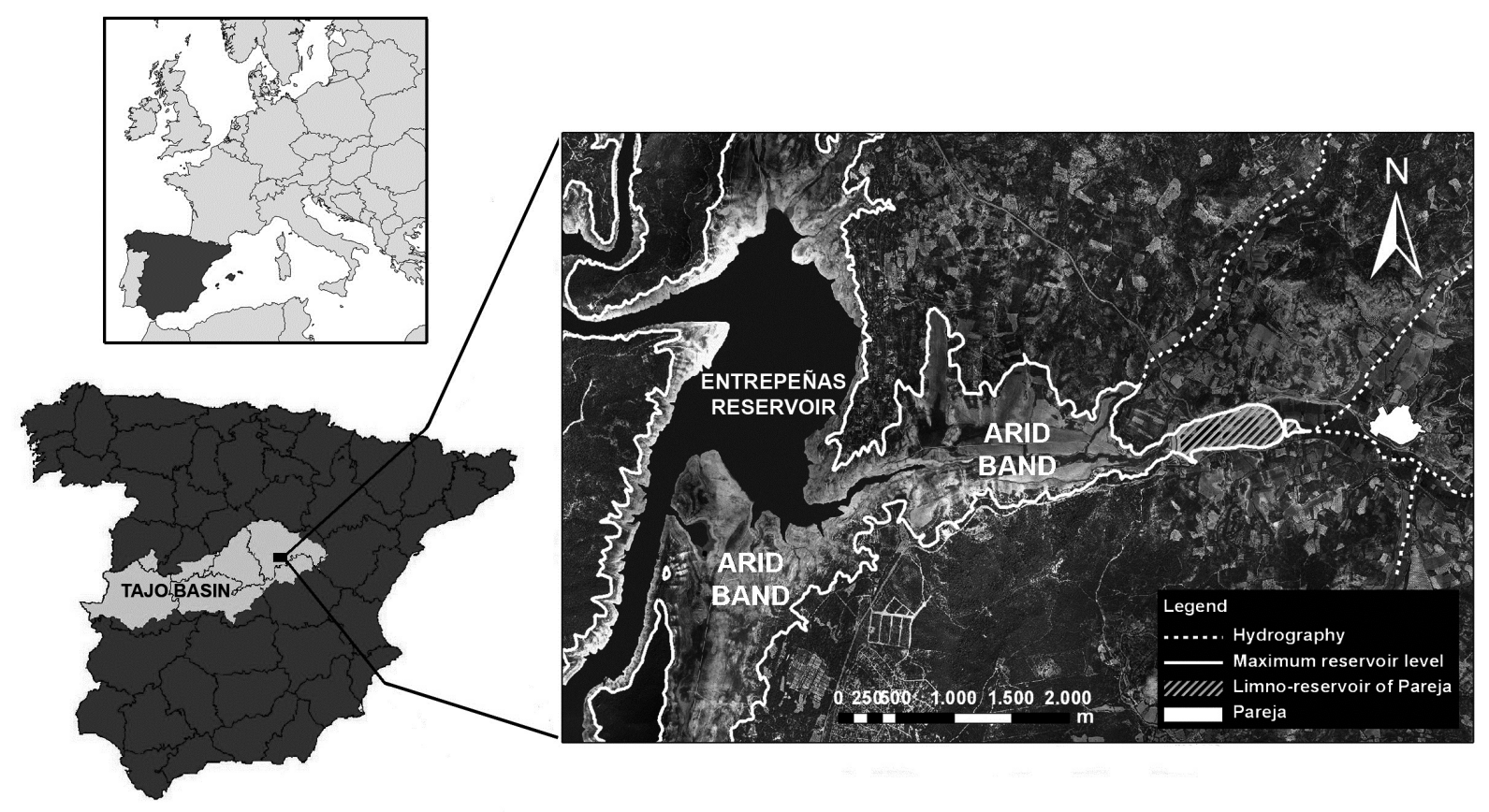

Figure 1. The location of the Pareja Limno-reservoir and a comparison of the volume of water stored in the Entrepeñas reservoir in 2006 with its maximum capacity (modified from Molina Navarro et al., 2010). Localización del Limnoembalse de Pareja y comparación del volumen de agua almacenado en el embalse de Entrepeñas en 2006 con su máxima capacidad (modificado de Molina Navarro et al., 2010). 
ile plastic containers were used to collect samples for total phosphorus (TP) determinations. Samples for geochemical analyses were collected in $125 \mathrm{ml}$ plastic bottles. Depth profiles of temperature, $\mathrm{pH}$, dissolved oxygen and conductivity were measured in $1 \mathrm{~m}$ increments with a YSI 6920 Multi-Parameter Water Quality Sonde probe (YSI Incorporated, Yellow Springs, OH, USA). During the 2009-2010 hydrological year, nearly monthly profiles of temperature and dissolved oxygen were made to better determine the stratification pattern. The transparency of the water body was measured using a Secchi disk in the two selected sampling sites. To analyse chlorophyll $a$ (CHL $a$ ) concentrations, 11 samples were collected and filtered in-situ with Whatman GF/F $47 \mu \mathrm{m}$ filters. A vacuum pump was connected to a car battery and used with a Millipore funnel. Subsequently, the filter was kept in tubes of dry ice and transported to the laboratory.

To analyse the phytoplankton, $250 \mathrm{ml}$ samples were collected in dark glass containers from the surface of the water body in the inflow and dam zones. The samples were fixed with acid Lugol's iodine. Zooplankton samples were collected with a $55 \mu \mathrm{m}$ mesh size net at the same sampling points. To collect these samples, the entire water column was sampled in the inflow zone. In the dam zone, vertical hauls were made from depths between the surface and approximately one metre from the bottom to avoid the effect of vertical migrations. At both sampling points, horizontal samples were also collected between depths of 1 and 2 metres. The net contents in each zone were combined to produce a unique sample. The sample was fixed with acid Lugol's iodine for transportation and preservation.

\section{Sample analysis}

Nitrogen compounds (nitrate, nitrite, and ammonia) were analysed in-situ with a LASA 100 portable photometer (HACH LANGE LTD, Manchester, UK). TP was determined in the laboratory following standard procedures with the LASA DR 2800 photometer method $(\mathrm{HACH}$ LANGE LTD, Manchester, UK). The geochemical analyses were performed by the "Centro de
Análisis de Aguas S.A.” laboratory. CHL $a$ was extracted from filters with $90 \%$ acetone $(15 \mathrm{ml}$, kept in the dark for 24 hours) and measured using the Parsons and Strickland formula (1965).

Phytoplankton samples were analysed with the Uthermöl technique (Uthermöl, 1958) and a Leica DMRIB microscope (Leica Microsystems, Wetzlar, Germany). A total of 25 or $50 \mathrm{ml}$ of the samples was allowed to settle depending on the content of inorganic matter. The largest species were counted at 100, 200 or $400 \times$ (depending on their size and density), and the smallest were counted at $1000 \times$. For the species counted at $100 \times$, the entire surface of the chamber was examined. For $200 \times$ or more, phytoplankton individuals were counted in transects or per field to achieve a total of at least 100 for the most common species (if possible). After settling, the zooplankton samples were analysed with a Leica Labovert microscope (Leica Microsystems) under a magnification of 100 to $400 \times$. Taxonomic determinations were made at the species level in the three primary zooplankton groups (copepods, rotifers and cladocerans). These identifications were based on several sources, including Dussart (1964), Koste (1978) and Alonso (1996). A total of $10 \mathrm{ml}$ of a fixed and homogenised sample was settled after every sampling survey. A taxonomic determination was performed for all zooplankton individuals found in the settling chamber. A semi-quantitative analysis of the settled sample was also performed with the Uthermöl technique.

\section{Data analysis}

Carlson's (1977) Trophic State Index (TSI) was calculated from the CHL $a$ and TP concentrations found at the dam and inflow zones of the Pareja Limno-reservoir. The limiting values specified in the trophic classification system of the OECD were also incorporated in the analysis (OECD, 1982), as were considerations of nitrogen compounds (e.g., Camargo \& Alonso, 2006).

To calculate the algal biovolume, the dimensions of at least 20 individuals per species (cells, filaments or colonies) were measured at 400 or $1000 \times$ magnification. Each species was assigned a geometric shape. The appropriate dimensions 
(length, width and diameter) were measured and used in formulae to calculate the cell volume. The measurements were made by image analysis with the LAS (Leica Application Suite) program. A number of the geometric shapes in Rott (1981) and Edler (1979) were used for reference. An abundance category was assigned to each zooplankton species according to the species' relative abundance. The categories of "low", "mid", "high" or "very high" were used for species whose individuals represented $0-5 \%, 5-15 \%$, $15-40 \%$ or $>40 \%$, respectively, of the total number of zooplankton individuals found in the settling chamber (the sample collected in autumn 2009 in the inflow zone showed an exceptionally low zooplankton density; only two zooplankton species were found and were assigned to the "low" and "mid" categories).

\section{RESULTS AND DISCUSSION}

\section{Physico-chemical and biological characteristics}

Figures $2 \mathrm{a}$ and $2 \mathrm{~b}$ show the depth-time distributions of the isopleths of temperature and dissolved oxygen, respectively, in the dam zone of the Pareja Limno-reservoir. The summer temperature stratification begins to disappear at the beginning of autumn. A period of vertical mixing follows. This period ends at the beginning of spring, when stratification begins again. The distribution of dissolved oxygen generally follows the temperature pattern. However, the dissolved oxygen concentrations decrease during the late winter and early spring at the bottom of the limno-reservoir. It is probable that high pre-
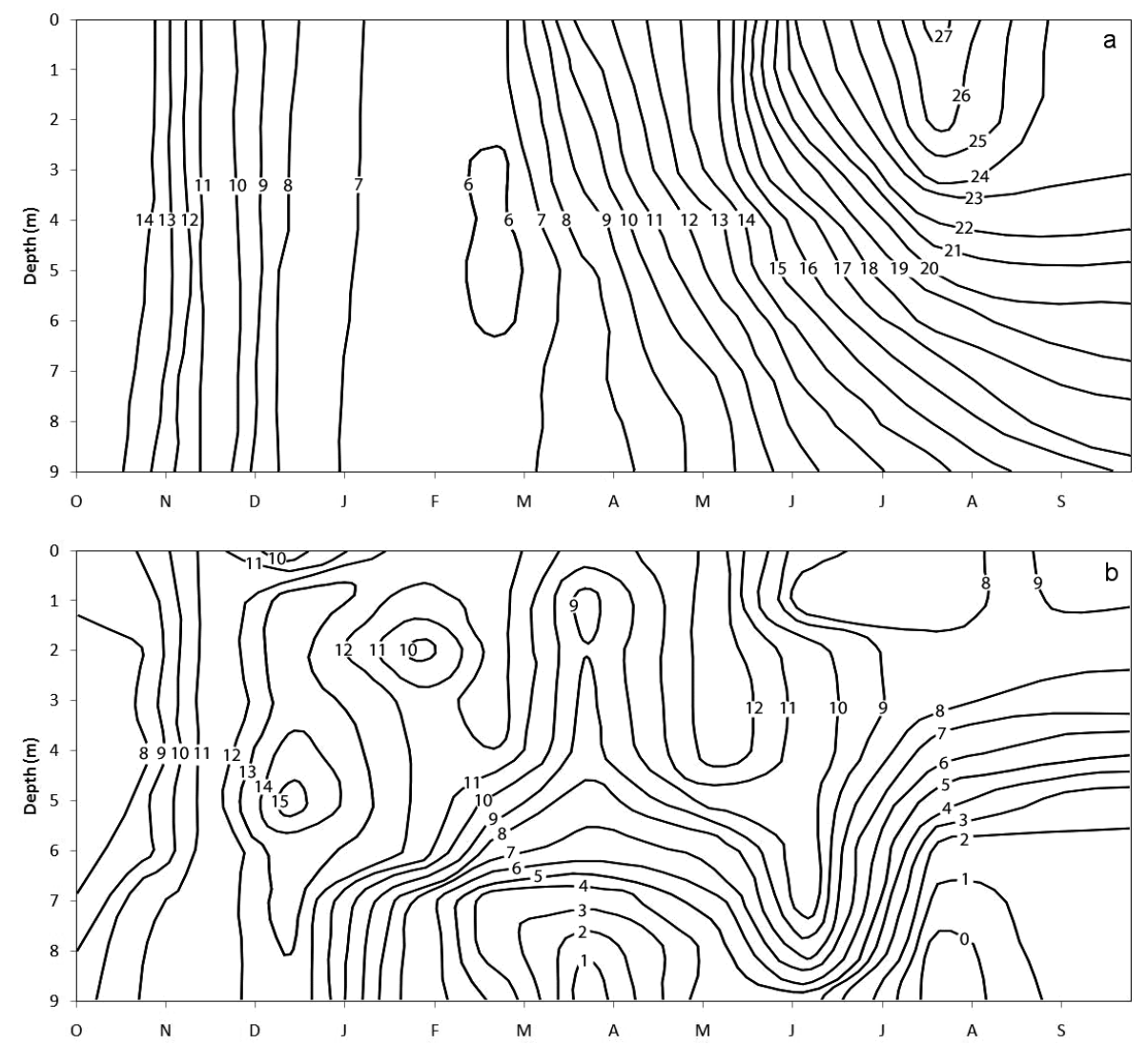

Figure 2. Depth-time distributions of isopleths of temperature $\left({ }^{\circ} \mathrm{C}\right)(\mathrm{a})$ and dissolved oxygen $(\mathrm{mg} / \mathrm{l})(\mathrm{b})$ in the dam zone of the Pareja Limno-reservoir during the hydrological year 2009-2010. Variación de los perfiles de temperatura $\left({ }^{\circ} \mathrm{C}\right)($ a) y de oxígeno disuelto $(\mathrm{mg} / \mathrm{l})(\mathrm{b})$ en la zona de presa del Limnoembalse de Pareja durante el año hidrológico 2009-10. 
cipitation caused cool, silt-laden runoff from the Ompólveda River to flow into the hypolimnion. The decomposition of the organic matter in the suspended solids may explain the decrease in the oxygen concentrations (Molina-Navarro et al., 2011). This phenomenon is discussed in Hobson et al. (2010).

The mean seasonal values for the principal limnological parameters at the surface at both sampling points are shown in Table 1 . The results obtained were generally similar in the dam and the inflow zones. The water was slightly alkaline, with $\mathrm{pH}$ ranges of 7.3-8.4 in the dam zone and 7.5-8.4 in the inflow zone. The conductivity values oscillated between $959 \mu \mathrm{S} / \mathrm{cm}$ and $1455 \mu \mathrm{S} / \mathrm{cm}$ in the dam zone, whereas the range of conductivity values in the inflow zone was 744-1464 $\mu \mathrm{S} / \mathrm{cm}$. Temporal differences in conductivity were observed. Lower values of conductivity occurred during the spring and winter, whereas higher values occurred during the summer and autumn (Table 1) due to the summer drought and the predominance of base flow. The water was sulphated-calcic, with average concentrations of $\mathrm{SO}_{4}^{2-}$ and $\mathrm{Ca}^{2+}$ of $561 \mathrm{mg} / 1$ and $262 \mathrm{mg} / 1$, and it was calcite-saturated.

Table 1 also shows the mean seasonal nutrient concentrations. The nitrate $\left(\mathrm{N}-\mathrm{NO}_{3}^{-}\right)$and nitrite $\left(\mathrm{N}-\mathrm{NO}_{2}^{-}\right)$concentrations were usually below the detection levels $(0.23 \mathrm{mg} / 1$ and $0.015 \mathrm{mg} / \mathrm{l}$, respectively). Except for a peak of $0.809 \mathrm{mg} / \mathrm{l}$ during winter 2009 in the inflow zone, the ammonium $\left(\mathrm{N}-\mathrm{NH}_{4}^{+}\right)$concentrations always ranged between $0.023 \mathrm{mg} / 1$ and $0.179 \mathrm{mg} / \mathrm{l}$. The highest concentrations of nitrogen compounds were found during the winter, when the Ompólveda River has its highest flow volume and increases the nutrient load into the limno-reservoir. According to the criteria in Dodds et al. (1998) and Camargo \& Alonso (2006), the nitrogen concentrations in Pareja Limno-reservoir indicates oligotrophic waters except during those winters when the Ompólveda River has a high flow volume. Dodds et al. (1998) suggest that the upper limit of total nitrogen for eutrophic temperate lakes is $1.26 \mathrm{mg} / \mathrm{l}$, whereas Camargo \& Alonso (2006) state that total nitrogen levels lower than 0.5$1.0 \mathrm{mg} / \mathrm{l}$ may prevent aquatic ecosystems from developing eutrophication.

The total phosphorus (TP) concentrations ranged from the detection level $(0.010 \mathrm{mg} / \mathrm{l})$ to $0.035 \mathrm{mg} / \mathrm{l}$, with a peak of $0.110 \mathrm{mg} / \mathrm{l}$ during winter 2010. During this season, the Ompólveda River had its highest flow volume. The water transparency was always higher in the dam zone than in the inflow zone (Table 1). The range of CHL $a$ concentration was generally $1-4 \mu \mathrm{g} / 1$ and showed higher values during the summer and autumn than during the winter and spring. According to OECD criteria (OECD, 1982), the TP con-

Table 1. Average seasonal values for the main physico-chemical and biological parameters in the Pareja Limno-reservoir. Valores medios estacionales de los principales parámetros físico-químicos y biológicos en el Limnoembalse de Pareja.

\begin{tabular}{|c|c|c|c|c|c|c|c|c|}
\hline & \multicolumn{4}{|c|}{ Dam Zone } & \multicolumn{4}{|c|}{ Inflow Zone } \\
\hline & Spring & Summer & Autumn & Winter & Spring & Summer & Autumn & Winter \\
\hline Temperature $\left({ }^{\circ} \mathrm{C}\right)$ & 17.3 & 24.6 & 10.4 & 7.1 & 17.0 & 24.6 & 10.4 & 7.7 \\
\hline Dissolved $\mathrm{O}_{2}(\mathrm{mg} / \mathrm{l})$ & 10.5 & 9.4 & 10.7 & 12.5 & 10.9 & 8.9 & 10.6 & 12.3 \\
\hline $\mathrm{pH}$ & 8.0 & 7.5 & 7.7 & 7.7 & 8.1 & 7.7 & 7.9 & 7.9 \\
\hline Conductivity $(\mu \mathrm{S} / \mathrm{cm})$ & 1183 & 1317 & 1405 & 1096 & 1181 & 1320 & 1408 & 1024 \\
\hline Ionic composition type & $\mathrm{SO}_{4}-\mathrm{Ca}$ & $\mathrm{SO}_{4}-\mathrm{Ca}$ & $\mathrm{SO}_{4}-\mathrm{Ca}$ & $\mathrm{SO}_{4}-\mathrm{Ca}$ & $\mathrm{SO}_{4}-\mathrm{Ca}$ & $\mathrm{SO}_{4}-\mathrm{Ca}$ & $\mathrm{SO}_{4}-\mathrm{Ca}$ & $\mathrm{SO}_{4}-\mathrm{Ca}$ \\
\hline $\mathrm{N}-\mathrm{NO}_{3}^{-}$ & $<0.31$ & $<0.23$ & $<0.23$ & 1.220 & $<0.31$ & $<0.23$ & $<0.23$ & $<0.64$ \\
\hline $\mathrm{N}-\mathrm{NO}_{2}^{-}$ & $<0.015$ & $<0.015$ & $<0.015$ & $<0.024$ & $<0.017$ & $<0.018$ & $<0.016$ & $<0.015$ \\
\hline $\mathrm{N}-\mathrm{NH}_{4}^{+}$ & 0.070 & 0.072 & 0.111 & 0.027 & 0.065 & 0.079 & 0.113 & 0.290 \\
\hline $\mathrm{TP}(\mathrm{mg} / \mathrm{l})$ & $<0.015$ & $<0.015$ & $<0.010$ & $<0.017$ & $<0.013$ & $<0.023$ & $<0.013^{*}$ & $<0.052$ \\
\hline Secchi depth (m) & 2.57 & 1.23 & 1.87 & 1.66 & 1.38 & 0.71 & 1.03 & 1.03 \\
\hline Chlorophyll a $\left(\mu \mathrm{g} \mathrm{l}^{-1}\right)$ & 1.30 & 1.93 & 2.28 & 1.16 & 1.20 & 3.52 & 2.38 & 1.73 \\
\hline Phytoplankton biomass (mg/l) & 0.24 & 0.79 & 0.63 & 0.16 & 0.38 & 0.81 & 0.53 & 0.12 \\
\hline
\end{tabular}

* It was not possible to detect TP in autumn 2009 because of the interference of another chemical compound in the analytic method. 
centrations were in the oligotrophic $(<0.1 \mathrm{mg} / \mathrm{l})$ and mesotrophic (0.1-0.35 $\mathrm{mg} / \mathrm{l})$ ranges (except for winter 2010). The CHL $a$ mean and maximum were $1.9 \mu \mathrm{g} / \mathrm{l}$ and $6.23 \mu \mathrm{g} / \mathrm{l}$, respectively. Both values were in the oligotrophic range $(<2.5 \mu \mathrm{g} / 1$ for mean CHL $a,<8.0 \mu \mathrm{g} / 1$ for maximum annual peak). However, the mean and minimum values of the Secchi depth in the dam zone were $1.83 \mathrm{~m}$ and $1.1 \mathrm{~m}$, respectively. These values were in the eutrophic range (3-1.5 m for the mean Secchi depth and 1.5-0.7 $\mathrm{m}$ for the annual minimum). Nevertheless, in lakes and reservoirs receiving high amounts of nonalgal particulate matter, Secchi disk transparency measurements might be expected to produce erroneous values (Carlson, 1977). This caveat applies to Pareja Limno-reservoir. Caramujo \& Boavida (2000) and Baião \& Boavida (2005) determined that the same caveat applied to the Secchi depth measurements in the Tajo River Basin reservoirs. Carlson's Trophic State Index (TSI) (Carlson, 1977) was calculated for the CHL $a$ and TP concentrations. These values varied between 24.2 and 48.5 for CHL $a$ and between $<37.4$ and 55.4 for TP (with the exception of the winter 2009 peak, which gave a TSI value for TP of 72.0). According to the Carlson model, Pareja Limno-Reservoir could be classified as mesotrophic (35-55) or even oligotrophic (25-35).
The results obtained suggest oligo-mesotrophic conditions in Pareja Limno-reservoir. This finding is consistent with the characteristics of the Ompólveda River Basin. The river is at the head of the Tajo River Basin, and eutrophication was not expected in Pareja Limno-reservoir The phytoplankton community was also studied in Pareja Limno-reservoir. The mean seasonal phytoplankton biomass values are shown in Table 1. Figure 3 shows the distribution of the different groups (in percentage of biomass) in the dam and the inflow zones.

The phytoplankton biomass was higher during the summer and autumn than during the spring and winter, in agreement with the higher concentrations of CHL $a$. The biomass values during the summer are a result of higher water temperatures, thermal stability and the enhanced light climate, whereas the values during the autumn respond to the beginning of the mixing period and the subsequent resuspension of nutrients and sunken algae in the limno-reservoir (Margalef, 1978; Reynolds, 1984; Souza et al., 2008; Hoyer et al., 2009). The total phytoplankton biomass and the distribution of groups were similar in the dam and the inflow zones. Chlorophyta showed the highest biomass during summer 2008 and 2009. This group was dominant in the inflow zone in 2008 and in the dam zone in 2009. Cryptophyta were dominant in both
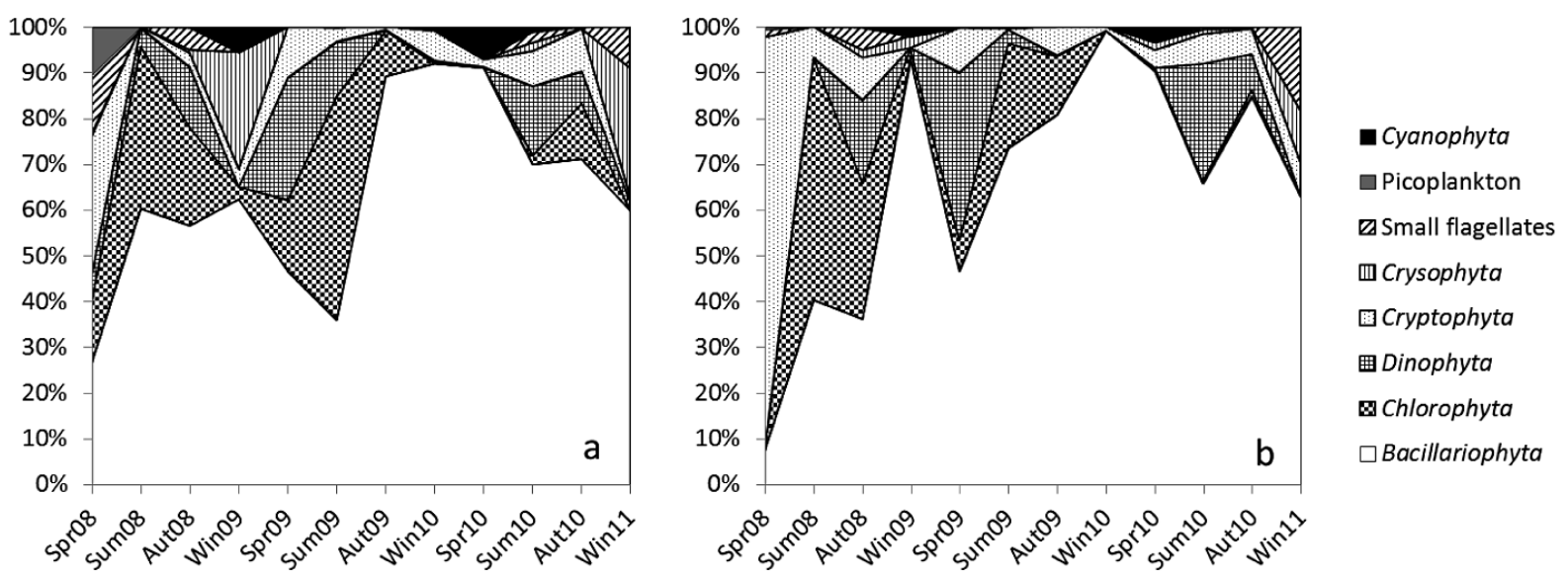

Figure 3. The distribution of phytoplankton groups (as a percentage of total biomass) during the study in the dam (a) and inflow (b) zones of the Pareja Limno-reservoir. Distribución de los grupos de fitoplancton (en porcentaje de biomasa) durante el estudio en las zonas de presa (a) y cola (b) del Limnoembalse de Pareja. 
zones in the first sample (spring 2008). Bacillariophyta (diatoms) were the most abundant taxonomic category and dominated the remainder of the samples. Dinophyta species were abundant in a number of samples but showed no clear temporal pattern. The representative species included Planctonema lauterbonii and Oocystis spp. for Chlorophyta, Cryptomonas spp. and Plagioselmis nannoplanctica for Cryptophyta, Cyclotella spp. and Cyclotella ocellata for Bacillariophyta and Ceratium hirundinella for Dinophyta.

\section{Zooplankton richness and relative abundance}

In total, 32 zooplankton species belonging to the three principal zooplankton groups (rotifers, copepods and cladocerans) were found in Pareja Limno-reservoir. These species included 17 rotifers, 13 cladocerans and only 2 copepods (Fig. 4). The total richness in the dam and inflow zone was the same for rotifers (13 species were found in both zones, but different species compositions were found in the two zones) and copepods ( 2 species), whereas the total richness of cladocerans was higher in the inflow zone (13 species) than in the dam zone (7 species). However, the average richness in each sample was 8 and 9 species in the dam and inflow zones, respectively. These results showed that the group of species present at each sampling time was variable. These findings are consistent with the statement by Margalef (1983) that zooplankton communities are usually composed of a small number of species. Rarefaction techniques were not used to determine the richness of the zooplankton. However, this methodological choice of rarefaction may not affect the results of the study because all zooplankton individuals found in the settling chamber in each sample were identified to obtain the richness value. The principal species found in Pareja Limno-reservoir are consistent with those described by other studies performed on the Iberian Peninsula (Armengol, 1978; Colomer, 2001; Conde-Porcuna et al., 2002; Baião \& Boavida, 2005). This similarity holds even for the species described by Margalef (1983) for a group of reservoirs that includes Entrepeñas Reservoir, which is adjacent to Pareja Limno-reservoir.
Colomer (2001) surveyed 77 Spanish reservoirs. For each reservoir, three sample collections were made at two sampling points, the dam and the inflow. The average number of species per reservoir was $23 \pm 6$. The relatively small size of the limno-reservoir may tend to produce a decrease in the number of species (Colomer, 2001; Wetzel, 2001). In view of this tendency, the number of zooplankton species in Pareja Limno-reservoir would seem to be relatively high. Moreover, it appears that the zooplankton community was not limited by the nutritional quality of the phytoplankton because diatoms (Bacillariophyta), whose nutritional quality is high (Conde-Porcuna et al., 2004), dominate the phytoplankton community. Although Pareja Limno-reservoir resembles a lake more than it resembles a reservoir, the comparison with reservoirs is appropriate. The zooplankton communities are very similarin both systems and studies of Iberian lakes are scarce (Spain has a few lakes and more than 1400 reservoirs) (Margalef, 1983; Colomer, 2001).

The analysis of rotifers showed that certain species, such as Polyarthra dolichoptera, Synchaeta pectinata and Asplanchna priodonta, occurred in most of the samples. P. dolichoptera and $S$. pectinata, absent from the dam zone in the first samples, showed the highest values of relative abundance (Fig. 4). These species are phytophagous and feed primarily on Cryptophyta, Chrysophyta and central diatoms (Pourriot, 1970, 1977), which dominate the phytoplankton community of Pareja Limno-reservoir. Both species are cold stenotherms and have been found to exhibit maxima at low temperatures (de Manuel, 2000). This pattern can be observed in Pareja Limno-reservoir, especially in the dam zone. In contrast, A. priodonta (very frequent in Spain) is eurythermic polyphagous and even predatory (Margalef, 1983; de Manuel, 2000; Wetzel, 2001). This species feeds on diatoms, dinoflagellates and other rotifers, such as Keratella cochlearis and $P$. dolichoptera (Guiset, 1977), which showed an important presence in Pareja Limno-reservoir.

Keratella species, which feed on algae, organic detritus and bacteria and tolerate a wide range of conductivities (de Manuel, 2000), were also 


\begin{tabular}{|c|c|c|c|c|c|c|c|}
\hline \multirow{3}{*}{ GROUP } & \multirow{3}{*}{ SPECIES } & \multicolumn{3}{|c|}{ DAM ZONE } & \multicolumn{3}{|c|}{ INFLOW ZONE } \\
\hline & & 2008 & 2009 & $2010 / 11$ & 2008 & 2009 & $2010 / 11$ \\
\hline & & \multicolumn{6}{|c|}{ RELATIVE ABUNDANCE } \\
\hline \multirow{17}{*}{ 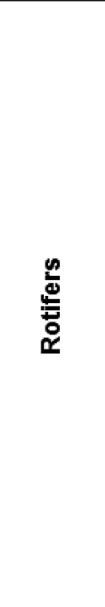 } & Polyarthra dolichoptera & & & & & & \\
\hline & Synchaeta pectinata & & & & & & \\
\hline & Asplanchna priodonta & & & & & & \\
\hline & Hexarthra fennica & & & & & & \\
\hline & Keratella quadrata & & & & & & \\
\hline & Keratella cochlearis cochlearis & & & & & & \\
\hline & Keratella cochlearis tecta & & & & & & \\
\hline & Gastropus stylifer & & & & & & \\
\hline & Lecane luna & & & & & & \\
\hline & Lepadella patella & & & & & & \\
\hline & Lecane bulla & & & & & & \\
\hline & Lepadella acuminata & & & & & & \\
\hline & Notholca squamula & & & & & & \\
\hline & Lecane lunaris & & & & & & \\
\hline & Brachionus calicyflorus & & & & & & \\
\hline & Platyias quadricornis & & & & & & \\
\hline & Keratella tropica & & & & & & \\
\hline
\end{tabular}

\begin{tabular}{|c|c|}
\hline \multirow{5}{*}{$\begin{array}{l}\frac{0}{8} \\
\frac{0}{8} \\
\text { 응 }\end{array}$} & Nauplius \\
\hline & Copepodito (Calanoide) \\
\hline & Copidodiaptomus numidicus \\
\hline & Copepodito (Cyclopide) \\
\hline & Tropocyclops prasinus \\
\hline
\end{tabular}

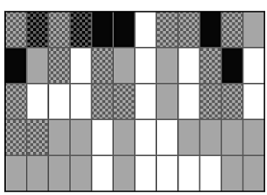

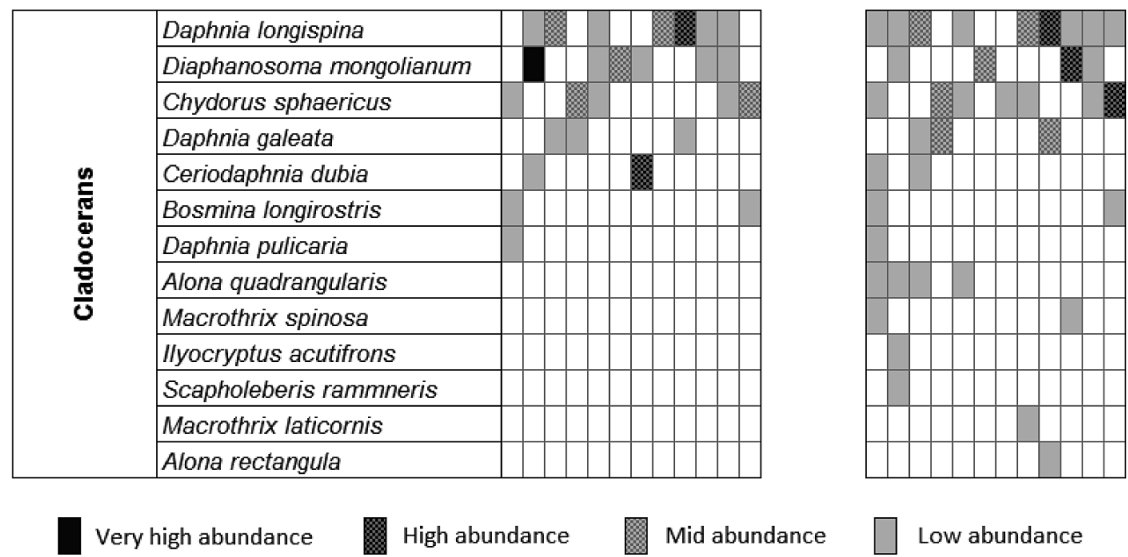

Figure 4. Presence and relative abundance of zooplankton species present during the study (spring 2008-winter 2011). Presencia y abundancia relativa de las diferentes especies de zooplancton durante el estudio (primavera 2008-invierno 2011).

present. $K$. quadrata was the first of these species to appear. It was subsequently replaced by $K$. cochlearis cochlearis or $K$. cochlearis tecta (the latter species only in the dam zone). This segregation between these two species was previously described by Margalef (1983). Another species found in many samples is Hexarthra fennica, described as euryhaline (i.e., tolerant of high conductivity) and seasonal. The highest relative abundances of this species were found during the summer, but a high relative abundance was also found during winter 2010. Other rotifer species occured only sporadically in the Pareja Limno-reservoir. Most of these species were found only in the dam zone or only in the inflow zone (Fig. 4).

Only two species of copepods, Copidodiaptomus numidicus (calanoid) and Tropocyclops prasinus (cyclopoid), were found in Pareja Limno-reser- 
voir. However, these species occurred in most of the samples. Their copepodite and naupliar stages were also identified (the naupliar stages of the two species were not differentiated). Zooplankton communities in Spanish reservoirs are generally composed of one diaptomid species $(C$. numidicus is the most abundant) and one or two cyclopid species, one of which is carnivorous (Margalef, 1983). This finding generally agrees with the results from Pareja Limno-reservoir except for the absence of the carnivorous cyclopid.

The naupliar stage showed the highest relative abundances in the copepods sampled (Fig. 4). This stage is favoured if the temperature, dissolved oxygen or food availability decrease. This stage is also favoured during the summer because it allows copepods to avoid fish predation (Wetzel, 2001). A comparison of the two copepod species present showed that $C$. numidicus generally exhibited higher relative abundances than $T$. prasinus. This difference was particularly evident during the second half of the study, when T. prasinus was not present in a number of samples. $T$. prasinus is herbivorous (not a filter-feeder), and microfiltering cladocerans have been found to replace herbivorous copepods in Spanish limnoreservoirs (Margalef, 1983).

Cladocerans showed the lowest relative abundances of the three groups of zooplankton. In general, rotifers and cladocerans (especially Daphnia species) share the same food resources (Wetzel, 2001; Conde-Porcuna et al., 2004). Therefore, high relative abundances of rotifers produce a decline in of cladoceran populations. Only one or two Daphnia species were present in most of the samples, as is usually the case in Spanish reservoirs (Margalef, 1983). D. longispina and D. galeata were the main representatives of the genus. Chydorus sphaericus, a macrofiltering species (as are Daphnia species) is also present in a number of samples, especially in the inflow zone.

The microfiltering Diaphanosoma mongolianum was found particularly during the summer, as Margalef (1983) and Caramujo \& Boavida (2000) have previously described. Other microfiltering species present (only in two samples per zone) are Ceriodaphnia dubia and
Bosmina longirostris. The first species is described as sporadically present in Spanish reservoirs, whereas the second is cosmopolitan but is found in more eutrophic conditions (Margalef, 1983; Caramujo \& Boavida, 2000). Many other cladoceran species were sporadically present only in the dam zone of the limno-reservoir and primarily in the first samples (Fig. 4).

Finally, although the value of zooplankton as an indicator of the trophic state is lower than the value of phytoplankton (Colomer, 2001), a number of findings about the zooplankton community of the Pareja Limno-reservoir suggest the oligo-mesotrophic state described above. These findings include the following: a high species richness (Colomer, 2001); a higher relative abundance of Copidodiaptomus numidicus (calanoid) than Tropocyclops prasinus (cyclopoid) (Maier, 1996; Caramujo \& Boavida, 2000; Parra et al., 2009); the absence of carnivorous copepod species (Caramujo \& Boavida, 2000); and the scarcity of Bosmina longirostris (Margalef, 1983; Caramujo \& Boavida, 2000). Nevertheless, these findings should be regarded cautiously, and further research should be performed in the Pareja Limno-reservoir to better determine the nature of the relationship between the zooplankton community and the trophic state of the water body.

\section{CONCLUSIONS}

The Pareja Limno-reservoir showed a warm monomictic stratification pattern, with one period of vertical mixing starting at the beginning of the autumn and one period of stratification starting at the beginning of the spring. The waters were sulphated-calcic and slightly alkaline. These waters showed conductivity values ranging from 744 to $1464 \mu \mathrm{S} / \mathrm{cm}$.

The highest nutrient concentrations (nitrogen compounds and total phosphorus) were generally found during the winter, whereas the maximum CHL $a$ values occurred during the summer and the autumn. The results of the trophic classification and the TSI index suggested an oligomesotrophic state in the Pareja Limno-reservoir. The phytoplankton biomass was greater during 
the summer and autumn than during the spring and winter. The Bacillariophyta represented the dominant taxonomic group in the phytoplankton community, followed by the Chlorophyta, Cryptophyta and Dinophyta.

32 zooplankton species were found in the Pareja Limno-reservoir. This level of species richness is high compared to that in other Spanish reservoirs. The total species richness was higher in the inflow zone than in the dam zone as a result of a higher richness of cladoceran species. The most representative species found are similar to those described by previous studies conducted on the Iberian Peninsula. Polyarthra dolichoptera, Synchaeta pectinata and Asplanchna priodonta showed the highest relative abundances among the rotifers found. These species are well adapted to the Pareja Limno-reservoir because of their feeding requirements. Rotifers and cladocerans generally share the same food resources. A high relative abundance of rotifers may produce a decrease in the cladoceran populations. In our study, cladocerans showed the lowest relative abundances of the groups investigated. Only two copepods, Copidodiaptomus numidicus and Tropocyclops prasinus were present. The former species generally showed a greater relative abundance.

\section{ACKNOWLEDGEMENTS}

Funding for this research came from the Social Action Committee of Ibercaja and the Government of Castilla-La Mancha (Science and Education Department, research project PAI080226-1758). The research team thanks the Pareja City Hall and the Confederación Hidrográfica del Tajo for their support. Eugenio Molina-Navarro received additional support from a predoctoral grant from the University of Alcalá.

\section{REFERENCES}

ALONSO, M. 1996. Crustacea, Branchiopoda. In: Fauna Ibérica, vol. 7. M. A. Ramos et al. (eds.) Museo de Ciencias Naturales, CSIC. Madrid. $486 \mathrm{pp}$.
ARMENGOL, J. 1978. Zooplankton crustaceans in Spanish reservoirs. Verh. Internat Verein. Limnol., 20: $1652-1656$.

BAIÃO, C. \& M. J. BOAVIDA. 2005. Rotifers of Portuguese reservoirs in river Tejo catchment: Relations with trophic state. Limnetica, 24(1-2): 103114.

CAMARGO, J. A. \& A. ALONSO. 2006. Ecological and toxicological effects of inorganic nitrogen pollution in aquatic ecosystems: A global assessment. Environment International, 32: 831-849.

CARAMUJO, M. J. \& M. J. BOAVIDA. 2000. The crustacean communities of river tagus reservoirs. Zooplankton structure as reservoir trophic state indicator. Limnetica, 18: 37-56.

CARLSON, R. E. 1977. A trophic state index for lakes. Limnology and Oceanography, 22(2): 361369.

COLOMER, M. G. S. 2001. Las comunidades de zooplancton de los embalses españoles. Ecosistemas, 10 (2). http://www.revistaecosistemas.net/ articulo.asp? $\mathrm{Id}=364$

CONDE-PORCUNA, J. M., E. RAMOS-RODRÍGUEZ \& C. PÉREZ-MARTÍNEZ. 2002. Correlations between nutrient concentrations and zooplancton populations in a mesotrophic reservoir. Freshwater Biology, 47: 1463-1473.

CONDE-PORCUNA, J. M., E. RAMOS-RODRÍGUEZ, E. \& R. MORALES-BAQUERO, R. 2004. El zooplancton como integrante de la estructura trófica de los ecosistemas lénticos. Ecosistemas, 13(2): 23-29.

DODDS, W. K., J. R. JONES \& E. B. WELCH. 1998. Suggested classification of stream trophic state: distributions of temperate streams types by chlorophyll, total nitrogen and phosphorous. Water Research, 32: 1455-1462.

DUSSART, B. 1964. Copépodes d' Espagne. Bull. Soc. Zool. Fr., 89: 117-125.

EDLER, L. (ed.). 1979. Recommendations on methods for marine biological studies in the Baltic Sea. Phytoplankton and chlorophyll. The Baltic Marine Biolgists. Publ No. 5. Gotab, Malmö.

GUISET, A. 1977. Stomach content in Asplanchna and Ploesma. Arch. Hydrobiol. Beih., 8: 222-225.

HOBSON, P., R. FABRIS, E. DEVELTER, L. G. LINDEN, M. D. BURCH \& J. D. BROOKES. 2010. Reservoir Inflow Monitoring for Improved Management of Treated Water Quality-A South Australian Experience. Water Resources Management, 24: 4161-4174. 
HOYER, A. B., E. MORENO-OSTOS, J. VIDAL, J. M. BLANCO, L. R. PALOMINO-TORRES, A. BASANTA, C. ESCOT \& F. J. RUEDA. 2008. The influence of external perturbations on the functional composition of phytoplankton in a Mediterranean reservoir. Hydrobiologia, 636: 49-64.

KOSTE, W. 1978. Rotatoria. Die Rädertiere Mitteleuropas, begründet von Max Voigt. Überordnung Monogononta. 2. Auflage neubeartbeitet von. Gebrüder Borntraeger. Berlin. Stuttgart. I. Text (673 pp). II Tafelband, (p. 234).

MAIER, G. 1996. Copepod communities in lakes of varying trophic degree. Archiv fur Hydrobiologie, 136(4): 455-465.

MARGALEF, R. 1983. Limnología. Omega. Barcelona. $1010 \mathrm{pp}$.

MARGALEF, R. 1978. Life-forms of phytoplankton as survival alternatives in an unstable environment. Acta Oceanol., 1: 493-509.

MINISTERIO DE MEDIO AMBIENTE Y COMITÉ NACIONAL ESPAÑOL DE GRANDES PRESAS. 1996. Embalses y Medio Ambiente. Centro de Publicaciones del Ministerio de Medio Ambiente, Madrid. 273 pp.

MOLINA-NAVARRO, E., S. MARTÍNEZ PÉREZ \& A. SASTRE MERLÍN. 2010. El Limnoembalse de Cola de Pareja (Guadalajara): aspectos medioambientales e hidrológicos. Boletín Geológico y Minero, 121(1): 69-80.

MOLINA-NAVARRO, E., S. MARTÍNEZ-PÉREZ, A. SASTRE-MERLÍN, J. SOLIVERI, I. FERNÁNDEZ-MONISTROL \& J. L. COPA-PATIÑO. 2011. Microbiological water quality and its relation to nitrogen and phosphorus at the Pareja Limno-reservoir (Guadalajara, Spain). Journal of Environmental Management, 92 (3): 773-779.

OECD. 1982. Eutrophication of Water: Monitoring, Assessment and Control. Organization of Economic Cooperation and Development. Paris, France. 154 pp. OFFICIAL JOURNAL OF THE EUROPEAN UNION,
22 December 2000, number 327, page 1. Directive 2000/60/EC of 23 October 2000 establishing a framework for the Community action in the field of water policy. European Parliament and Council. PARRA, G., N. G. MATIAS, F. GUERRERO \& M. J. BOAVIDA. 2009. Short term fluctuactions of zooplankton abundance during autumn circulation in two reservoirs with contrasting trophic state. Limnetica, 28: 175-184.

PARSONS, T. R. \& J. D. H. STRICKLAND. 1965. A practical handbook of sea water analysis. Bulletin of the Fisheries Research Board of Canada. $212 \mathrm{pp}$.

POURRIOT, R. 1970. Quelques Trichocerca (Rotifères) et leurs régimes alimentaires. Ann. Hydrobiol., 1(2): 155-171.

POURRIOT, R. 1977. Food and feeding habits of Rotifera. Arch. Hydrobiol. Beih., 8: 243-260.

REYNOLDS, C. S. 1984. The Ecology of Phytoplankton. Cambridge University Press, Cambridge. $384 \mathrm{pp}$.

RODRÍGUEZ CABELLOS, J. A. 1995. Obras de corrección del impacto generado por el régimen de explotación del embalse de Orellana sobre la avifauna acuática (Extremadura, España). Confederación Hidrográfica del Guadiana. 6 pp.

ROTT, E. 1981. Some results from phytoplankton counting intercalibrations. Schweizerische Zeitschrift für Hydrologie, 43 (1): 34-61.

SOUZA, M. B. G., C. F. A. BARROS, F. BARBOSA, E. HAJNAL \& J. PADISÁK. 2008. Role of atelomixis in replacement of phytoplankton assemblages in Dom Helvécio Lake, South-East Brazil. Hydrobiologia, 607: 211-224.

UTERMÖHL, H. 1958. Zur Vervollkommung der quantitativen Phytoplankton-Methodik. Mitt. Int. Verein. Theor. Angew. Limnol., 9, 1-38.

WETZEL, R. G. 2001. Limnology. Lake and River Ecosystems. $3^{\text {rd }}$ edition. Academic Press-Elsevier. San Diego, USA. 1006 pp. 